This is the peer reviewed version of the following article: Eur. J. Inorg. Chem. 2016,15-16, 2424-2431,

which has been published in final form at: https://doi.org/10.1002/ejic.201501433

\title{
About the stability of trimeric beryllium hydroxide scorpionate complexes
}

\author{
Dominik Naglav, Briac Tobey, Christoph Wölper, Dieter Bläser, Georg Jansen and Stephan Schulz*[a]
}

„Dass ich erkenne, was die Welt Im Innersten zusammenhält, Schau' alle Wirkenskraft und Samen, Und Tu's nicht mehr in Worten kramen." - Johann W. v. Goethe

\begin{abstract}
The controlled hydrolysis of $\mathrm{TpBeCl}$ ( $\mathrm{Tp}=$ trispyrazolylborate $\left[\mathrm{HB}\left(\mathrm{C}_{3} \mathrm{~N}_{2} \mathrm{H}_{3}\right)_{3}\right]^{-}$) with $\mathrm{H}_{2} \mathrm{O}$ and $\mathrm{D}_{2} \mathrm{O}$ in presence of $\mathrm{N}, \mathrm{N}$-Diisopropylethylamine (DIPEA) quantitatively yield the trimeric beryllium hydroxide scorpionate complexes $\left[\mathrm{Be}_{3}(\mu-\mathrm{OX})_{3}(\mathrm{Tp})_{3}\right](\mathrm{X}=\mathrm{H}$ 1, D 2) containing six membered $\mathrm{Be}_{3} \mathrm{O}_{3}$ rings according to single crystal X-ray diffraction studies and theoretical calculations. 1 shows a dynamic structure in solution as was proven by temperature dependent ${ }^{1} \mathrm{H}$ - and ${ }^{9} \mathrm{Be}$ NMR spectroscopy. In addition, the structure of $\left[\mathrm{BeBr}_{3}(\mu-\mathrm{OH})_{3}(\mathrm{Br})_{3}(\text { thf })_{6}\right]$, which was obtained from hydrolysis of a solution of $\mathrm{BeBr}_{2}$ in tetrahydrofuran (thf) and $\mathrm{CHCl}_{3}$, is reported.
\end{abstract}

\section{Introduction}

Beryllium chemistry has led a cinderella-like existence compared to the heavier group 2 elements and $\mathrm{Mg}$ in particular, due to the toxicity of beryllium and its compounds. ${ }^{[1]}$ This has changed significantly in the last decade and highly interesting compounds such as beryllium diorganyls, ${ }^{[2]} \mathrm{NHC}$-stabilized beryllium dihalides, ${ }^{[3]}$ diorganyls, ${ }^{[4]}$ and hydride $\left({ }^{i-P r} \mathrm{NHC}\right.$ $\mathrm{Be}(\mathrm{Me}) \mathrm{H})^{[5]}$ as well as the Lewis acid-base adducts $\left[\left(\mathrm{Cy}_{3} \mathrm{P}\right)_{2} \mathrm{Pt}\right.$ $\mathrm{Be}(\mathrm{Cl}) \mathrm{X}] \quad(\mathrm{X}=\mathrm{Cl}, \mathrm{Me})$ and others have been prepared. ${ }^{[6,7]}$ Moreover, the search for $\mathrm{Be}(\mathrm{I})$ complexes and the use of $\mathrm{BeF}_{2}$ as fluoride acceptor in liquid ammonia pushed the beryllium chemistry recently. ${ }^{[8,9]}$

Beryllium complexes typically adopt tetrahedral coordination modes in aqueous solution ${ }^{[10]}$ and tend to form six-membered rings, in which three $\mathrm{Be}^{2+}$-cations are bridged by an anion $\left[\mathrm{Be}_{3}\left(\mu-\mathrm{A}^{-}\right)_{3}(\text { Donor })_{6}\right]^{3+},{ }^{[11]}$ as was initially discovered in hydrolysis studies of beryllium halides in liquid ammonia. ${ }^{[9]}$ Recent interest in the coordination chemistry of beryllium scorpionate complexes in non-aqueous solvents resulted in the synthesis of TpBeX compounds $\left(X=F, C l, B r, I, H, D, N_{3}\right)$, which were extensively studied by heteronuclear NMR spectroscopy. ${ }^{[12]}$

$\mathrm{TpBeOH}$, which was initially prepared by Sohrin et al., adopts a trimeric structure in the solid state including $\mathrm{N}-\mathrm{Be}$ interactions as well as $\mathrm{N}-\mathrm{H}-\mathrm{O}$ hydrogen bonds. ${ }^{[13]}$ It was the first example of a poly(pyrazolyl)borate ligand stabilizing a molecule by multiple-point bindings. Since the authors rather focused on the use of a variety of Tp-ligands as ion-size selective extraction reagent for aqueous solutions of alkaline-earth metals, heteronuclear NMR spectroscopic studies were not performed

[a] S. Schulz, * D. Naglav, C. Wölper, G. Jansen, B. Tobey Faculty of Chemistry, University of Duisburg-Essen (Campus Essen) Universitätsstraße 7, 45141 Essen

E-mail: stephan.schulz@uni-due.de; https://www.unidue.de/ak_schulz/index_en.php

Supporting information for this article is given via a link at the end of the document. and information on the thermal stability of these trimeric complexes is also missing. We became interested in the structure of this complex in non-aqueous solution as well as in the gas phase and solid state and analyzed the stability of $[\mathrm{TpBeOH}]_{3}$ by time- and temperature-dependent NMR spectroscopy and computational methods. Furthermore we report on the low-temperature solid state structure of the solvated form $[\mathrm{TpBeOH}]_{3}$ toluene (1) and a redetermination of its solvent-free hydroxy-deuterated analogue $[\mathrm{TpBeOD}]_{3}(2)$ as well as of $\left[\text { thf }_{2} \mathrm{BeOH}\right]_{3} \mathrm{Br}_{3} \cdot \mathrm{CHCl}_{3}(3)$.

\section{Results and Discussion}

Reactions between $\mathrm{TpBeCl}$ and $\mathrm{H}_{2} \mathrm{O}$ or $\mathrm{D}_{2} \mathrm{O}$ in the presence of DIPEA as $\mathrm{HCl}$-trapping agent quantitatively gave $\mathrm{TpBeOH} 1$ and $T p B e O D$ 2, which were isolated as colorless crystalline solids from saturated solutions in toluene upon storage at $-30{ }^{\circ} \mathrm{C}$.

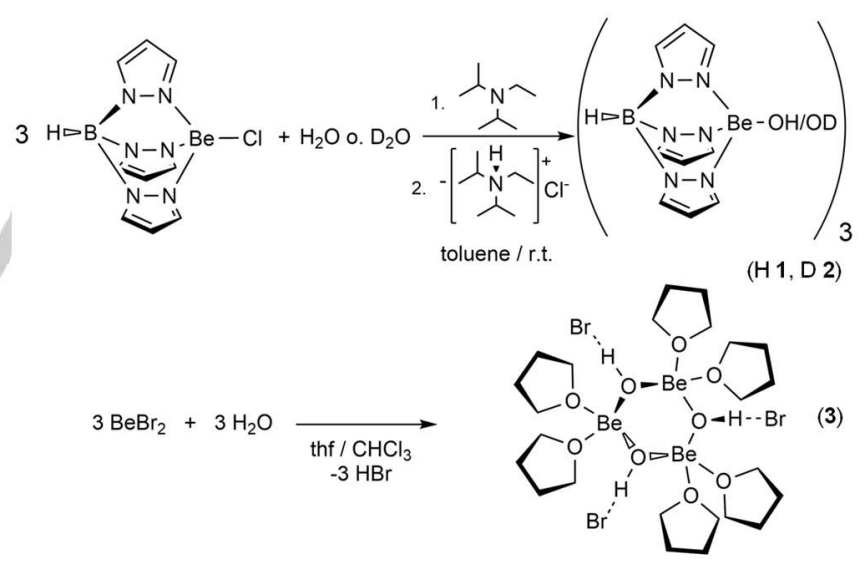

Scheme 1. Synthesis of $1-3$

The solid state structures of $\mathbf{1}-\mathbf{3}$, which were determined by single crystal X-ray diffraction at $100 \mathrm{~K}$, are consistent with the structure that was published before. ${ }^{[13]} \mathbf{1}-\mathbf{3}$ each adopt trimeric structures in the solid state with a central $\mathrm{Be}_{3} \mathrm{O}_{3}$ ring. However, the solvated form (1) does no longer resemble $\mathrm{C}_{3}$ symmetry as was initially reported for solvent-free $[\mathrm{TpBeOH}]_{3}$ and as was observed for $[\mathrm{TpBeOD}]_{3}$ 2. The central structural motif in 1 - a six-membered $\mathrm{Be}_{3} \mathrm{O}_{3}$ ring - is almost flat (r.m.s deviation of the atoms from the best plane $0.1481 \AA$ ), but $\mathrm{Be} 1$ and $\mathrm{O} 2$ deviate in one direction $(-0.2219(10),-0.1906(10))$ and $\mathrm{Be} 2, \mathrm{Be} 3, \mathrm{O} 1$ and $\mathrm{O} 3$ in the opposite direction $(0.1427$ (0.0010), 0.1193 (0.0010), 0.0667 (0.0009), $0.0838(0.0009)$ ), resulting in a very flat boattype conformation in 1 with $\mathrm{Be} 1$ and $\mathrm{O} 2$ as it "stern" and "bow". 
This is the major difference to the already known solvent free form. Since a boat-type conformation is not compatible with the 3-fold symmetry of $\mathbf{2}$ and $\mathbf{3}$, we observe a (again very flat) chairtype conformation in 1 . The $\mathrm{Be}$ atoms are coordinated by two nitrogen atoms of the Tp ligand, resulting in a tetrahedral environment, while the third pyrazolyl group forms an intramolecular $\mathrm{N} \cdots \mathrm{H}$ hydrogen bond. The $\mathrm{Be}-\mathrm{O}$ bond lengths differ slightly and a shorter and a longer one alternate within the the $\mathrm{Be}_{3} \mathrm{O}_{3}$ ring.

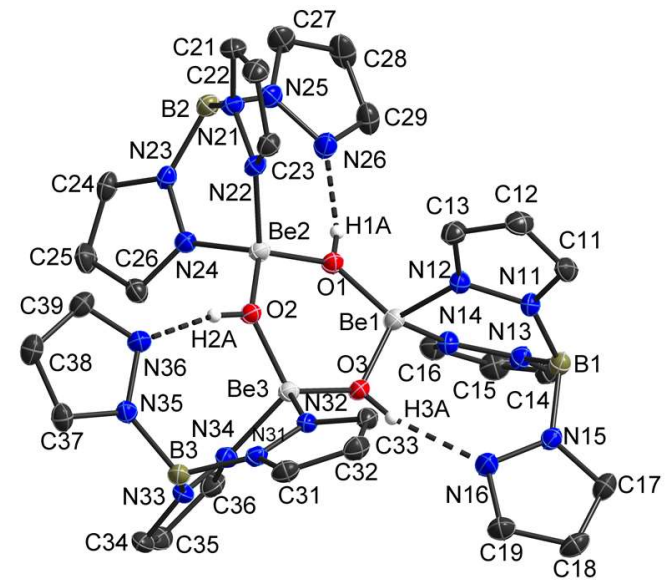

Figure 1. Molecular structure of 1. Thermal ellipsoids are displayed at $50 \%$ probability rate. Only $\mathrm{OH}$ hydrogen atoms are shown for clarity.

Single crystals of $\mathbf{3}$ were obtained while trying to synthesize $\mathrm{Be}\left(\mathrm{Br}_{2}\right)$ (thf) $)_{2}$. However, 3 can be quantitatively synthesized by slow hydrolysis of a solution of $\mathrm{BeBr}_{2}$ in thf with wet $\mathrm{CHCl}_{3}$, similar to a reaction that was described for hydrolysis of $\mathrm{BeCl}_{2}$ in liquid ammonia. ${ }^{[9]} 3$ also forms a $\mathrm{Be}_{3} \mathrm{O}_{3}$ ring as was observed for 1 and 2, the atoms deviate even less from the best plane (r.m.s. $0.0911 \AA$ ) and the conformation is rather twisted. Two thf ligands complete the tetrahedral coordination sphere of each Be atom. The bromine anions are not coordinated but serve as acceptors for hydrogen bonds. The difference in the $\mathrm{Be}-\mathrm{O}$ bond-lengths in $\mathbf{3}$ is less pronounced than in $\mathbf{1}$.

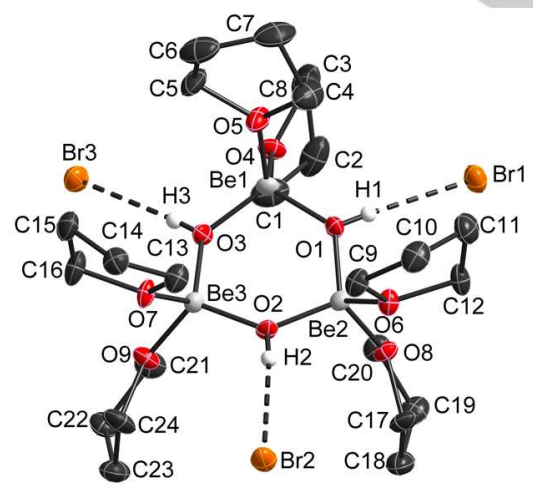

Figure 2. Molecular structure of 3 . Thermal ellipsoids are displayed at $50 \%$ probability rate. Only $\mathrm{OH}$ hydrogen atoms are shown for clarity.
Table 1. Selected bond lengths $(\AA)$ and bond angles $\left({ }^{\circ}\right)$ as observed in 1 - 3 .

\begin{tabular}{|c|c|c|c|}
\hline & 1 & $2^{[12]}$ & 3 \\
\hline $\mathrm{Be} 1-01 / \mathrm{O} 3$ & $\begin{array}{l}1.574(2) \\
1.596(2)\end{array}$ & $\begin{array}{l}1.595(4) \\
1.581(4)\end{array}$ & $\begin{array}{l}1.566(4) \\
1.572(4)\end{array}$ \\
\hline $\mathrm{Be} 2-\mathrm{O} 1 / \mathrm{O} 2$ & $\begin{array}{l}1.592(2) \\
1.575(2)\end{array}$ & & $\begin{array}{l}1.576(4) \\
1.572(4)\end{array}$ \\
\hline $\mathrm{Be} 3-\mathrm{O} 2 / \mathrm{O} 3$ & $\begin{array}{l}1.599(2) \\
1.565(2)\end{array}$ & & $\begin{array}{l}1.573(4) \\
1.572(4)\end{array}$ \\
\hline Be1-N12/N14 & $\begin{array}{l}1.760(2) \\
1.740(2)\end{array}$ & $\begin{array}{c}1.735(3) \\
1.751(3)\end{array}$ & - \\
\hline Be2-N22/N24 & $\begin{array}{c}1.755(2) \\
1.755(2)\end{array}$ & - & - \\
\hline Be3-N32/N34 & $\begin{array}{l}1.748(2) \\
1.751(2)\end{array}$ & - & - \\
\hline N12-Be1-N14 & $99.8(1)$ & $99.5(2)$ & - \\
\hline N22-Be2-N24 & $98.3(1)$ & - & - \\
\hline N32-Be3-N34 & $99.4(1)$ & - & - \\
\hline $\mathrm{Be} 1-\mathrm{O} 1-\mathrm{Be} 2$ & $126.8(1)$ & $127.0(2)$ & $127.6(2)$ \\
\hline $\mathrm{Be} 2-\mathrm{O} 2-\mathrm{Be} 3$ & $127.2(1)$ & - & $130.0(2)$ \\
\hline $\mathrm{Be} 1-\mathrm{O} 3-\mathrm{Be} 3$ & $125.4(1)$ & - & $126.8(2)$ \\
\hline O1-Be1-O3 & $109.4(1)$ & $108.0(2)$ & $111.3(2)$ \\
\hline O1-Be2-O2 & $109.3(1)$ & - & $110.2(2)$ \\
\hline O2-Be3-O3 & $110.9(1)$ & - & $109.6(3)$ \\
\hline
\end{tabular}

\section{NMR studies in solution}

Temperature-dependent ${ }^{1} \mathrm{H}$ - and ${ }^{9} \mathrm{Be}$ NMR spectra of 1 were measured in the temperature range from $-80{ }^{\circ} \mathrm{C}$ to $+160{ }^{\circ} \mathrm{C}$ in non-coordinating solvents (toluene and/or 1,3,5-trimethylbenzene) in order to investigate any conformational changes.

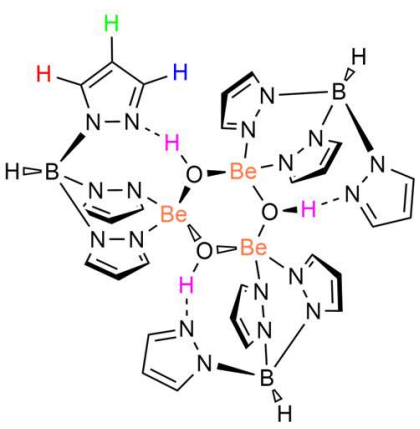

Scheme 2. Lewis drawing of 1 and labelling of the nuclei as addressed in the ${ }^{1} \mathrm{H}$ and ${ }^{9} \mathrm{Be}$ NMR experiments.

The NMR data clearly prove that at low temperature, one pyrazolyl arm is coordinating to the $\mathrm{OH}$-bridge in the sixmembered $\mathrm{Be}_{3} \mathrm{O}_{3}$ ring, whereas the other two are coordinated to 
the beryllium atom. The ${ }^{9} \mathrm{Be}$ chemical shift in toluene (3.02 ppm) is within the typical range of tetrahedral coordinated beryllium atoms. The $\mathrm{OH}$ group shows a ${ }^{1} \mathrm{H}$ chemical shift of $8.83 \mathrm{ppm}$. At ambient temperature the ${ }^{9} \mathrm{Be}$ resonance is shifted to $4.40 \mathrm{ppm}$ and a rather large high-field shift of the $\mathrm{OH}$-group to $8.46 \mathrm{ppm}$ is observed in the ${ }^{1} \mathrm{H}$ NMR spectrum. At $+80^{\circ} \mathrm{C}$ the ${ }^{9} \mathrm{Be}$ resonance is shifted to $4.29 \mathrm{ppm}$ and the ${ }^{1} \mathrm{H}$ resonance of the $\mathrm{OH}$-group to $8.19 \mathrm{ppm}$. In addition, the gap between the two resonances of the protons in the pyrazolyl ligand (coordinating to $\mathrm{Be}$ and to $\mathrm{OH})$ decreases with higher temperatures. Similar temperature effects were observed for the ${ }^{1} \mathrm{H}$ resonance of the $\mathrm{OH}$ group [8.70 ppm $\left.\left(-60^{\circ} \mathrm{C}\right), 8.37 \mathrm{ppm}\left(+20^{\circ} \mathrm{C}\right), 8.23 \mathrm{ppm}\left(+60^{\circ} \mathrm{C}\right)\right]$ and the ${ }^{9} \mathrm{Be}$ resonance $\left[4.36 \mathrm{ppm}\left(-20^{\circ} \mathrm{C}\right), 4.38 \mathrm{ppm}\left(+20^{\circ} \mathrm{C}\right), 4.22\right.$ ppm $\left.\left(+60{ }^{\circ} \mathrm{C}\right)\right]$ in a solution of $1,3,5$-trimethylbenzene and toluene (9:1 mixture). These data indicate that the trimeric structure of $[\mathrm{TpBeOH}]_{3}$ is still preserved in solution over the entire temperature regime up to $80^{\circ} \mathrm{C}$. The small high-field shift of these signals rather result from the temperature increase than from a conformational change.

Further heating of 1 to higher temperatures $\left(100{ }^{\circ} \mathrm{C}, 120^{\circ} \mathrm{C}\right.$, $140{ }^{\circ} \mathrm{C}, 160^{\circ} \mathrm{C}$ ) resulted the formation of new beryllium species in solution, which showed resonances in the ${ }^{9} \mathrm{Be}$ NMR spectrum in the range of $4.53 \mathrm{ppm}$ to $5.07 \mathrm{ppm}$ (Fig. 3), in addition to the major signal at $4.20 \mathrm{ppm}$ of the trimeric compound 1. Moreover, the ${ }^{1} \mathrm{H}$ NMR resonance of the $\mathrm{OH}$-group broadens at about $+60{ }^{\circ} \mathrm{C}(8.23 \mathrm{ppm})$ and exhibits a shift to $8.03 \mathrm{ppm}$ at $+100{ }^{\circ} \mathrm{C}$ (Fig. 4). The signal becomes sharper upon further heating and is shifted towards higher field [7.95 ppm $\left(120{ }^{\circ} \mathrm{C}\right), 7.85 \mathrm{ppm}$ $\left.\left(140{ }^{\circ} \mathrm{C}\right), 7.75 \mathrm{ppm}\left(160^{\circ} \mathrm{C}\right)\right]$ with increasing temperature.

The shifts of the resonances in the ${ }^{1} \mathrm{H}$ NMR spectra as well as the appearance of the new beryllium species in the ${ }^{9} \mathrm{Be}$ NMR spectrum at high temperatures $\left(>140^{\circ} \mathrm{C}\right)$ are fully reversible and the ${ }^{1} \mathrm{H}$ and ${ }^{9} \mathrm{Be}$ NMR spectra taken of the heated sample after cooling to ambient temperature are identical to those obtained before heating. These findings hint to a dynamic fragmentation of the $[\mathrm{TpBeOH}]_{3}$ trimer 1 in solution at high temperatures. Therefore, we became interested in investigating the stability of the trimer by computing the interaction energy of the monomers within the trimer via quantum mechanical methods. Additionally, the results of the computations are compared to the solid state structure.

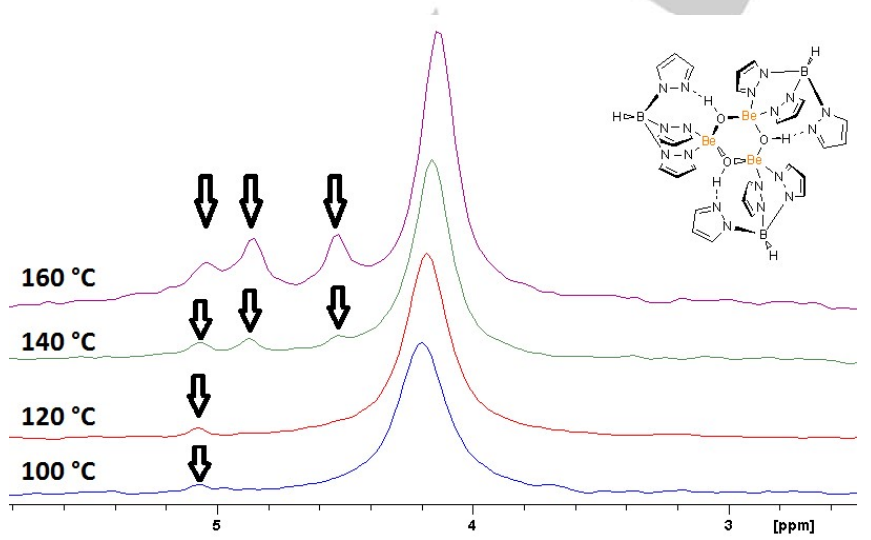

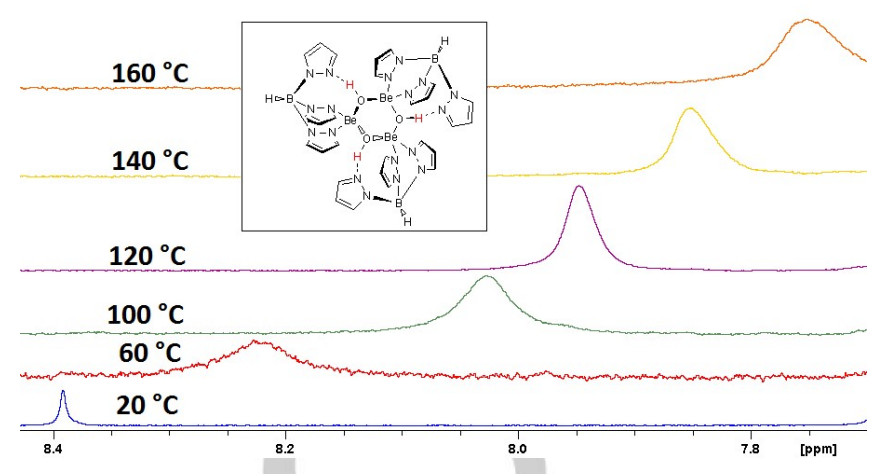

Figure 4. ${ }^{1} \mathrm{H}$ chemical shifts of 1 at different temperatures.

Table 2. ${ }^{1} \mathrm{H}$ and ${ }^{9} \mathrm{Be}$ chemical shifts of 1 in toluene- $d_{8}$ at different temperatures.

\begin{tabular}{|c|c|c|c|c|c|c|c|}
\hline Temp. & $\begin{array}{c}{ }^{9} \mathrm{Be} \\
(\mathrm{ppm})\end{array}$ & $\begin{array}{c}{ }^{1} \mathrm{H}(\mathrm{OH}) \\
(\mathrm{ppm})\end{array}$ & \multicolumn{2}{|c|}{$\begin{array}{c}{ }^{1} \mathrm{H}(1) \\
(\mathrm{ppm})\end{array}$} & \multicolumn{2}{c|}{$\begin{array}{c}{ }^{1} \mathrm{H}(3) \\
(\mathrm{ppm})\end{array}$} & \multicolumn{2}{c|}{$\begin{array}{c}{ }^{1} \mathrm{H}(2) \\
(\mathrm{ppm})\end{array}$} \\
\hline \multicolumn{2}{|c|}{ intensity } & $1 \mathrm{H}$ & $6 \mathrm{H}$ & $3 \mathrm{H}$ & $6 \mathrm{H}$ & $3 \mathrm{H}$ & $6 \mathrm{H}$ \\
\hline$-80^{\circ} \mathrm{C}$ & n.d. & 8.83 & 5.93 & 5.71 & 7.18 & 7.70 & 7.60 \\
\hline$-60^{\circ} \mathrm{C}$ & 5.72 & 8.77 & 5.93 & 5.76 & 7.22 & 7.71 & 7.66 \\
\hline$-40^{\circ} \mathrm{C}$ & 4.78 & 8.71 & 5.93 & 5.80 & 7.26 & 7.72 & 7.66 \\
\hline$-20^{\circ} \mathrm{C}$ & 4.53 & 8.64 & 5.93 & 5.83 & 7.30 & 7.72 & 7.65 \\
\hline $0^{\circ} \mathrm{C}$ & 4.43 & 8.56 & 5.92 & 5.86 & 7.34 & 7.72 & 7.65 \\
\hline$+20^{\circ} \mathrm{C}$ & 4.40 & 8.46 & 5.91 & 5.88 & 7.36 & 7.72 & 7.64 \\
\hline$+40^{\circ} \mathrm{C}$ & 4.35 & 8.37 & 5.91 & 5.90 & 7.39 & 7.71 & 7.63 \\
\hline$+60^{\circ} \mathrm{C}$ & 4.33 & 8.29 & 5.91 & 5.90 & 7.40 & 7.70 & 7.62 \\
\hline$+80^{\circ} \mathrm{C}$ & 4.29 & 8.19 & 5.92 & 5.89 & 7.41 & 7.69 & 7.61 \\
\hline
\end{tabular}

Table 3. ${ }^{1} \mathrm{H}$ and ${ }^{9} \mathrm{Be}$ Chemical shifts of 1 in a mixture of $1,3,5-$ trimethylbenzene and toluene- $d_{8}(9: 1)$ at different temperatures.

\begin{tabular}{|c|c|c|c|c|c|c|c|}
\hline Temp. & $\begin{array}{c}{ }^{9} \mathrm{Be} \\
(\mathrm{ppm})\end{array}$ & $\begin{array}{c}{ }^{1} \mathrm{H}(\mathrm{OH}) \\
(\mathrm{ppm})\end{array}$ & \multicolumn{2}{|c|}{$\begin{array}{c}{ }^{1} \mathrm{H}(1) \\
(\mathrm{ppm})\end{array}$} & \multicolumn{2}{c|}{${ }^{1} \mathrm{H}(3)$} & \multicolumn{2}{c|}{$\begin{array}{c}{ }^{1} \mathrm{H}(2) \\
(\mathrm{ppm})\end{array}$} & \multicolumn{2}{c|}{$(\mathrm{ppm})$} \\
\hline \multicolumn{2}{|c|}{ intensity } & $1 \mathrm{H}$ & $6 \mathrm{H}$ & $3 \mathrm{H}$ & $6 \mathrm{H}$ & $3 \mathrm{H}$ & $6 \mathrm{H}$ \\
\hline$-60^{\circ} \mathrm{C}$ & n.d. & 8.70 & 5.93 & 5.81 & n.d. & 7.71 & 7.63 \\
\hline$-20^{\circ} \mathrm{C}$ & 4.37 & 8.57 & 5.91 & 5.86 & 7.27 & 7.70 & 7.62 \\
\hline$+20^{\circ} \mathrm{C}$ & 4.38 & 8.34 & 5.90 & 5.89 & 7.33 & 7.68 & 7.59 \\
\hline$+60^{\circ} \mathrm{C}$ & 4.22 & 8.23 & 5.87 & 5.92 & 7.37 & 7.67 & 7.58 \\
\hline$+100^{\circ} \mathrm{C}$ & 4.20 & 8.03 & 5.85 & 5.93 & 7.40 & 7.69 & 7.61 \\
\hline$+120^{\circ} \mathrm{C}$ & 4.18 & 7.95 & 5.85 & 5.93 & 7.41 & 7.65 & 7.54 \\
\hline$+140{ }^{\circ} \mathrm{C}$ & 4.16 & 7.85 & 5.84 & 5.94 & 7.42 & 7.64 & 7.54 \\
\hline$+160^{\circ} \mathrm{C}$ & 4.14 & 7.75 & 5.84 & 5.95 & 7.42 & 7.63 & 7.52 \\
\hline
\end{tabular}


Since eleven crystal structures are already documented in the Cambridge Structure Database (CSD) which display the central $\left[(\mathrm{BeOH})_{3}\right]^{3+}$ unit, ${ }^{[14]}$ we considered it worth further investigating this general structural motif (as well as possible alternatives) by quantum chemical calculations (vide infra).

\section{Theoretical investigations}

The gas phase structure of the $[\mathrm{TpBeOH}]_{3}$ trimer was obtained by optimizing the geometry of the crystal structure of 1 using RI-DFT-D3 methods ${ }^{[15]}$ using the PBE functional[16] with the QZVPP basis sets ${ }^{[17]}$ in the Turbomole package ${ }^{[18]}$. The structure of the monomer $\mathrm{TpBeOH}$ and a postulated dimer $[\mathrm{TpBeOH}]_{2}$ were built from scratch and optimized through the same method. As the method used is usually not prone to a high influence by BSSE (basis set superposition error), the interaction energies in $[\mathrm{TpBeOH}]_{3}$ and $[\mathrm{TpBeOH}]_{2}$ were simply computed by subtracting the appropriate number of monomer energies and dividing the remainder by three and two, respectively. Additional single-point counter-poise-corrected SCS-RI-MP2 calculations ${ }^{[19]}$ using the TZVPP basis set ${ }^{[17]}$ were performed on the trimer to make sure that the interaction energies were accurate. Furthermore, CSM-corrections (continuum solvation model) using the COSMO-approach ${ }^{[20]}$ with default parameters and the dielectric constant of toluene $(\varepsilon=2.3741)$ were applied in singlepoint calculations upon the systems optimized in the DFT calculations that also showed no relevant change. Per bond and total interaction energies of $[\mathrm{TpBeOH}]_{3}$ and $[\mathrm{TpBeOH}]_{2}$ are summarized in table 4 . The interaction energy in $[\mathrm{TpBeOH}]_{3}$ is rather high, with a $100.3 \mathrm{~kJ} / \mathrm{mol}$ gain, when compared with the energy of three monomers, while it is significantly lower in the dimeric species.

Table 4. Interaction energies in $\mathrm{kJ} / \mathrm{mol}$ as obtained from quantum chemical calculations.

\begin{tabular}{|l|l|l|l|l|l|}
\hline & $\begin{array}{l}\text { trimer } \\
(\mathrm{DFT})\end{array}$ & $\begin{array}{l}\text { trimer } \\
(\mathrm{COSMO})\end{array}$ & $\begin{array}{l}\text { trimer } \\
(\mathrm{MP} 2)\end{array}$ & $\begin{array}{l}\text { dimer } \\
(\mathrm{DFT})\end{array}$ & $\begin{array}{l}\text { dimer } \\
(\mathrm{COSMO})\end{array}$ \\
\hline $\begin{array}{l}\text { per } \\
\text { bond }\end{array}$ & -100.3 & -86.8 & -91.4 & -54.3 & -43.6 \\
\hline total & -300.9 & -260.4 & -274.1 & -109.0 & -87.24 \\
\hline
\end{tabular}

The gas phase structure of $[\mathrm{TpBeOH}]_{3}$ (Fig. 5) is similar to the crystal structure, showing a six-membered $\mathrm{Be}_{3} \mathrm{O}_{3}$ ring as central structural unit. In contrast to the crystal structure, which shows a boat-type conformation, it is slightly twisted into a chairtype conformation and tends towards being $\mathrm{C}_{3}$-symmetric. Comparable results have previously reported by Dehnicke et al. for the $\left[\mathrm{Be}_{3}(\mu-\mathrm{OH})_{3}\left(\mathrm{H}_{2} \mathrm{O}\right)_{6}\right]^{3+}$ cation. ${ }^{[6 \mathrm{~d}]}$ While this cation is known to adopt both chair-type and boat-type conformations in the solid state, ${ }^{[13 b, 21]}$ it forms a nearly planar $\mathrm{C}_{3}$-symmetric $\left[\mathrm{Be}_{3}(\mathrm{OH})_{3}\right]$ sixmembered ring in the gas phase. ${ }^{\left[{ }^{[d]}\right]}$ Packing effects as well as hydrogen bridges are most likely responsible for the different conformations of the $\left[\mathrm{Be}_{3}(\mu-\mathrm{OH})_{3}\left(\mathrm{H}_{2} \mathrm{O}\right)_{6}\right]^{3+}$ cation in the solid state. As seen in the crystal structure, only two of the three arms of each Tp-ligand are bonded directly to one $\mathrm{Be}$ atom, while the third one forms a $\mathrm{N} \cdots \mathrm{H}$ hydrogen bond with the hydroxide group. A closer inspection of the bond lengths between $\mathrm{Be}$ and $\mathrm{O}$ within the six-membered ring clearly shows that there are three short and three long bonds, defining the monomeric entities and revealing the $\mathrm{N} \cdots \mathrm{H}$ hydrogen bond as an intermolecular interaction between these monomers. As a consequence, the formation of $[\mathrm{TpBeOH}]_{3}$ from three monomers is probably driven by an intercalation mechanism, where one of the arms of the Tpligand disengages from the $\mathrm{Be}$ atom to form an interaction with the hydroxide group in order to accommodate the formation of an additional Be-O-bond, since the beryllium cation is very oxophilic and the Lewis acidity difference between an $\mathrm{OH}$-group or an $\mathrm{N}$-group is not very large. The aromatic side arms of the Tp-ligand are slightly inclined towards one side of the ring, leaving one side of the ring more open while forming three $\mathrm{CH}$ $\pi$-interactions on the other side. This is in remarkable contrast to the crystal structure of $[\mathrm{TpBeOH}]_{3}$, in which two monomeric units are twisted in one direction, while the other is twisted in the other direction. This leads to a $\mathrm{CH}-\pi$-interaction on either side of the ring and two $\mathrm{CH}-\pi$-interactions near the plane of the sixmembered ring between a ligand-arm that is bonded to $\mathrm{Be}$ and one that interacts with the hydroxide group.

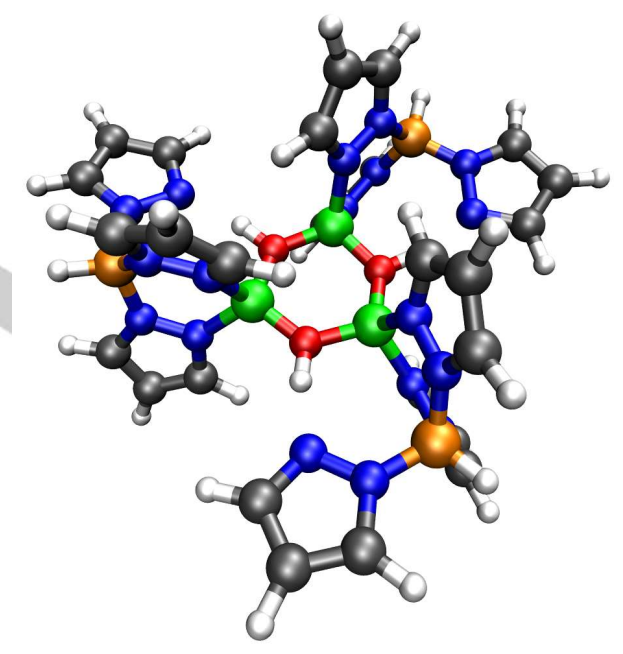

Figure 5. Theoretical gas phase structure of trimeric 1.

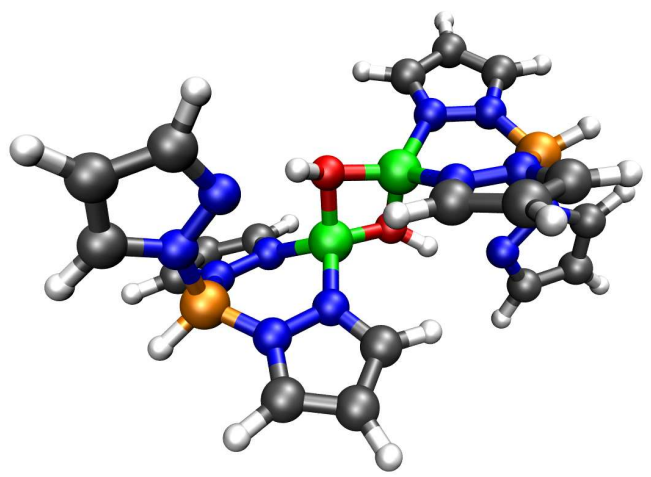

Figure 6. Theoretical gas phase structure of dimeric 1.

The dimer species (Fig. 6) shows a very similar structure to $[\mathrm{TpBeOH}]_{3}$ despite the increased ring strain within the four 
membered ring. Again hydrogen bonds with the third arm of the Tp-ligand are present, showing two significantly shorter Be-Obonds, which clearly bisect the dimer, and $\mathrm{CH}$ - $\mathrm{m}$-interactions on one side of the ring, leaving the other side quite open. As a consequence, the $\mathrm{Be}_{2} \mathrm{O}_{2}$ ring is highly distorted with a $\mathrm{Be}-\mathrm{O}-\mathrm{O}$ Be torsion angle of $155^{\circ}$.

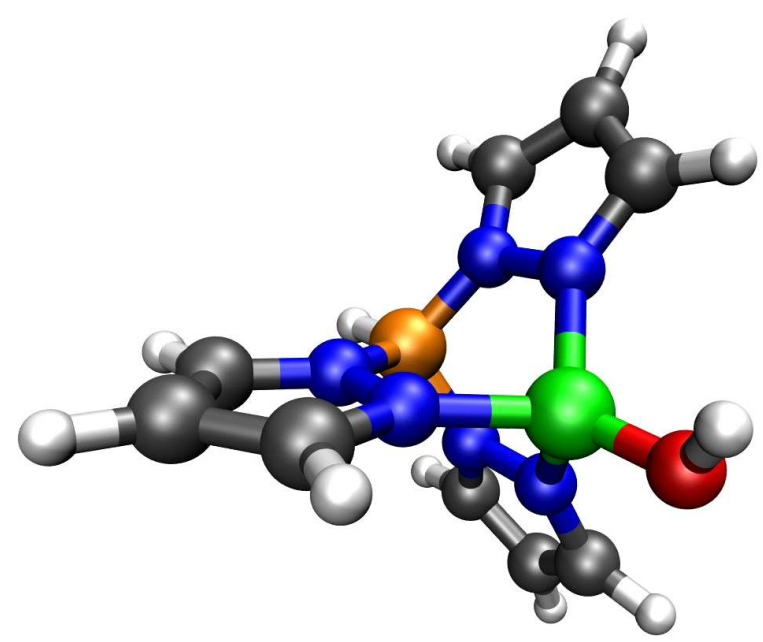

Figure 7. Theoretical gas phase structure of monomeric 1.

Important Be-N and Be-O bond lengths and angles (table 6) and hydrogen interactions (table 7) as experimentally observed (1) and calculated for $[\mathrm{TpBeOH}]_{3},[\mathrm{TpBeOH}]_{2}$ and $\mathrm{TpBeOH}$.

Table 5: Important bond lengths and angles in 1 and in the calculated structures of $[\mathrm{TpBeOH}]_{3},[\mathrm{TpBeOH}]_{2}$ and $\mathrm{TpBeOH}$ (average values)

\begin{tabular}{|c|c|c|c|c|}
\hline & XRD 1 & trimer & dimer & monomer \\
\hline Be-N (short) & 1.75 & 1.74 & 1.74 & 1.78 \\
\hline Be-N (long) & 3.43 & 3.41 & 3.38 & - \\
\hline Be-O (short) & 1.57 & 1.57 & 1.58 & 1.51 \\
\hline $\mathrm{Be}-\mathrm{O}$ (long) & 1.60 & 1.60 & 1.64 & - \\
\hline $\mathrm{O}-\mathrm{H}$ & 0.84 & 1.00 & 0.99 & 0.96 \\
\hline $\mathrm{Be}-\mathrm{O}-\mathrm{Be}$ & $\begin{array}{l}126.8 \\
127.2 \\
125.4\end{array}$ & 126.7 & 84.7 & - \\
\hline $\mathrm{O}-\mathrm{Be}-\mathrm{O}$ & $\begin{array}{l}109.4 \\
109.3 \\
110.9\end{array}$ & 111.0 & 92.8 & - \\
\hline $\mathrm{H}-\mathrm{B}-\mathrm{Be}$ & $\begin{array}{l}\text { 154.1, } \\
\text { 155.1, }\end{array}$ & 154.7 & 155.2 & 179.6 \\
\hline
\end{tabular}

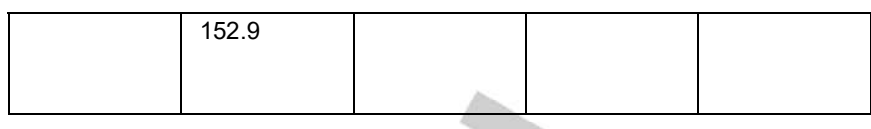

Table 6: Important hydrogen interactions in $\mathbf{1}$ and in the calculated structures of $[\mathrm{TpBeOH}]_{3}$ and $[\mathrm{TpBeOH}]_{2}$ (av. values).

\begin{tabular}{|c|c|c|c|c|c|c|}
\hline & D & $A$ & $d(D-H)$ & $\mathrm{d}(\mathrm{H}-\mathrm{A})$ & $d(D-A)$ & $\Varangle(D-H-A)$ \\
\hline XRD 1 & $\mathrm{O}$ & $\mathrm{N}$ & 0.84 & 1.97 & 2.79 & $163.7^{\circ}$ \\
\hline & $\mathrm{O}$ & $\mathrm{N}$ & 0.85 & 1.96 & 2.79 & $166.0^{\circ}$ \\
\hline & O & $\mathrm{N}$ & 0.83 & 1.99 & 2.79 & $165.4^{\circ}$ \\
\hline trimer & 0 & $\mathrm{~N}$ & 1.00 & 1.72 & 2.71 & $167.9^{\circ}$ \\
\hline dimer & $\mathrm{O}$ & $\mathrm{N}$ & 0.99 & 1.81 & 2.74 & $156.4^{\circ}$ \\
\hline XRD 1 & C & $C(\pi)$ & 0.95 & 3.51 & 4.21 & $132.6^{\circ}$ \\
\hline & C & $C(\pi)$ & 0.95 & 2.88 & 3.82 & $170.0^{\circ}$ \\
\hline & C & $C(\pi)$ & 0.95 & 3.07 & 3.93 & $152.5^{\circ}$ \\
\hline & C & $C(\pi)$ & 0.95 & 3.43 & 3.82 & $107.4^{\circ}$ \\
\hline trimer & C & $C(\pi)$ & 1.09 & 2.85 & 3.86 & $154.6^{\circ}$ \\
\hline dimer & C & $C(\pi)$ & 1.09 & 3.10 & 3.40 & $96.3^{\circ}$ \\
\hline XRD 1 & $\mathrm{C}$ & $N(\pi)$ & 0.95 & 3.42 & 4.14 & $134.9^{\circ}$ \\
\hline & C & $N(\pi)$ & 0.95 & 3.51 & 4.21 & $145.1^{\circ}$ \\
\hline & $\mathrm{C}$ & $N(\pi)$ & 0.95 & 3,26 & 4,04 & $141,3^{\circ}$ \\
\hline & C & $N(\pi)$ & 0.95 & 2,98 & 3,82 & $118,8^{\circ}$ \\
\hline trimer & C & $N(\pi)$ & 1.09 & 2.96 & 3.93 & $149.0^{\circ}$ \\
\hline dimer & C & $N(\pi)$ & 1.09 & 3.10 & 3.61 & $109.2^{\circ}$ \\
\hline
\end{tabular}

The Be- $\mathrm{N}$ distance in the monomer is elongated compared to those in the dimer and trimer, indicating that the bonding of the three arms of the Tp-ligand to Be atoms creates tension, which might be the driving force in the formation of the trimer. The formation of additional Be-O-bonds leads to a shortening of the other $\mathrm{Be}-\mathrm{O}$ bond lengths. These additional bonds are more favored in $[\mathrm{TpBeOH}]_{3}$ than in $[\mathrm{TpBeOH}]_{2}$ possibly due to tension in the four-membered ring, which is reflected in the interaction energy of the dimer and the torsions in the ring. This corroborated further by the hydrogen bonds and $\mathrm{CH}-\pi$ interactions, which are stronger in the trimer. The change in the $\mathrm{O}-\mathrm{H}$ bond lengths and the O-N distances further illustrates the strengthening of the hydrogen bond between the hydroxide group and the ligand when comparing $[\mathrm{TpBeOH}]_{2}$ with the $[\mathrm{TpBeOH}]_{3}$. Differences of the $\mathrm{Be}-\mathrm{O}$ and $\mathrm{Be}-\mathrm{N}$ distances between the crystal structure and the gas phase structure of 
$[\mathrm{TpBeOH}]_{3}$ are minimal and can be ignored. The $\mathrm{O}-\mathrm{H}$ bond length in the crystal structure is shorter due to systematic errors omnipresent in X-ray diffraction results.

The hydrogen interactions in the crystal structure - due to its unsymmetrical shape, which is probably facilitated through packing effects - show much higher variations from its average values compared to those in the gas phase structures. This leads to the crystal structure having some $\mathrm{CH}-\mathrm{C}(\pi)$ and $\mathrm{CH}-\mathrm{N}(\pi)$ distances that are smaller than those in the trimer gas phase structure though not with a significant margin. Due to the different geometry these interactions seem to be stronger in the dimer. As this finding does not correlate with the calculated interaction energies, it is expected that the $\mathrm{CH}-\mathrm{m}$ interactions do not have a significant impact on the interaction energies. In a preliminary investigation constricting the trimer into a $\mathrm{C}_{\mathrm{s}^{-}}$ symmetric flat shape the impact of the $\mathrm{CH}-\pi$ interactions was estimated to be about $3 \mathrm{~kJ} / \mathrm{mol}$. Though this is a very small contribution, it is apparently sufficient to at least in part dictate the final geometries in the gas phase structures and the crystal structure. Due to the systematic errors mentioned above, the best way to compare the $\mathrm{OH}-\mathrm{N}$ interactions between crystal structure and gas phase structure is to compare the $\mathrm{O}-\mathrm{N}$ distances, which show that the interactions are quite similar between the three contributing atoms. Small changes in angles though seem to be common.

The Be-O-Be and the O-Be-O angles in $[\mathrm{TpBeOH}]_{3}$ and $[\mathrm{TpBeOH}]_{2}$ are quite near to the angles one can find in the respective regular polygons and are thus not unexpected. The $\mathrm{H}-\mathrm{B}-\mathrm{Be}$ angle denotes in which angle the ligands attach to the $\mathrm{Be}$ atoms. As expected this is almost $180^{\circ}$ for the monomer and is lower in the dimer and trimer, though the difference between $[\mathrm{TpBeOH}]_{2}$ and $[\mathrm{TpBeOH}]_{3}$ does not seem to be significant. No significant contrast can be found between gas phase structure and crystal structure concerning these angles, other than the latter having more variations in its values.

NBO (natural bond orbitals) and SEN (shared electron numbers) analyses were performed to investigate the bonding situations. Values are summarized in table 7 and table 8.

Table 7. Calculated charges of $[\mathrm{TpBeOH}]_{3},[\mathrm{TpBeOH}]_{2}$ and $\mathrm{TpBeOH}$ from NBO analysis.

\begin{tabular}{|c|c|c|c|c|c|}
\hline NBO & $\mathrm{Be}$ & $\mathrm{O}$ & $\mathrm{H}$ & $\mathrm{N}(\mathrm{Be})$ & $\mathrm{N}(\mathrm{H})$ \\
\hline trimer & 1.664 & -1.374 & 0.501 & -0.440 & -0.329 \\
\hline dimer & 1.649 & -1.362 & 0.511 & -0.477 & -0.333 \\
\hline monomer & 1.649 & -1.306 & 0.461 & -0.458 & - \\
\hline
\end{tabular}

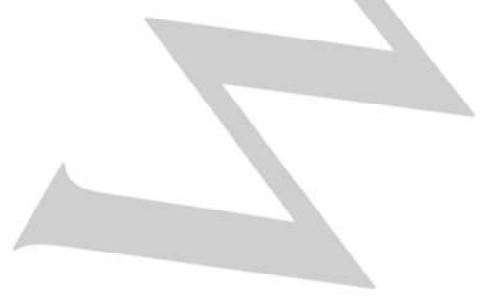

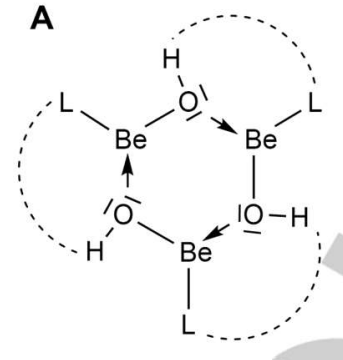

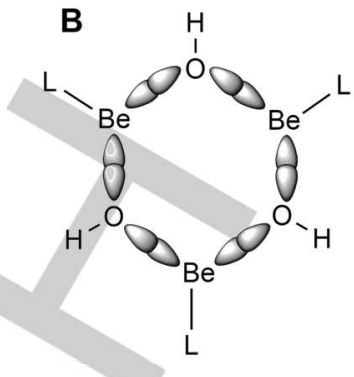

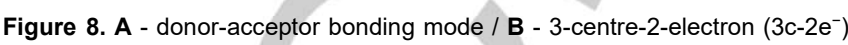
bonding mode.

While the charges on $\mathrm{Be}$ and $\mathrm{O}$ do change from monomer to dimer to trimer, these changes seem hardly significant. The most significant change is the increasing charge on $\mathrm{O}$, which is probably due to the additional Be-O bonds, and the increase in charge on $\mathrm{H}$, which is probably due to the formation of the hydrogen bonds.

Table 8. Calculated two-center shared electron numbers of $[\mathrm{TpBeOH}]_{3}$ $[\mathrm{TpBeOH}]_{2}$ and $\mathrm{TpBeOH}$.

\begin{tabular}{|c|c|c|c|c|}
\hline NBO & Be-O (short) & Be-O (long) & O-H & $(\mathrm{O}) \mathrm{H}-\mathrm{N}$ \\
\hline trimer & 0.4010 & 0.2697 & 0.9341 & 0.1226 \\
\hline dimer & 0.5689 & 0.3098 & 1.0788 & 0.0852 \\
\hline monomer & 0.3643 & - & 1.1991 & - \\
\hline
\end{tabular}

The hydrogen bond strength steadily increases from the monomer to the trimer as is reflected by the decrease of the $\mathrm{O}-\mathrm{H}$ SEN and the increase in (O)H-N SEN. Be-O SEN do not seem to follow any significant trend other than being the highest in the dimer, which might be due to its geometry or simply an artifact of the calculations. No significant multi-center SEN were found, other than those found in the aromatic arms of the ligand.

\section{Conclusions}

Beryllium hydroxides tend to form six-membered rings constituted of three $\mathrm{Be}-\mathrm{OH}$ units. This well know structural motif was also observed in $\mathbf{1}-\mathbf{3}$ and studied in detail using single crystal X-ray diffraction, NMR spectroscopy and computational calculations. This trimeric complex $[\mathrm{TpBeOH}]_{3}$ is stable in solution up to $80{ }^{\circ} \mathrm{C}$ but shows signs of a fully reversible disaggregation at higher temperatures (up to $160{ }^{\circ} \mathrm{C}$ ) as was shown by ${ }^{9} \mathrm{Be}$ NMR spectroscopy. Quantum chemical calculations verified that the stability of $[\mathrm{TpBeOH}]_{3}$ is based on a strong interaction between its constituent monomers which amounts to about $300 \mathrm{~kJ} / \mathrm{mol}$ in the gas phase and $260 \mathrm{~kJ} / \mathrm{mol}$ in toluene. The gas phase structure shows almost $\mathrm{C}_{3}$-symmetry and the $\mathrm{CH}-\mathrm{m}$ interactions comparable to those observed in the solid crystal structure. The energy of these $\mathrm{CH}-\pi$ interactions is very small $(\sim 3 \mathrm{~kJ} / \mathrm{mol})$ and consequently the structure of $[\mathrm{TpBeOH}]_{3}$ is very flexible. This can also be observed in the solid state since both boat (1) and chair (2) conformations were 
observed depending on whether solvent molecules are present or not. This leads to the crystal structures of 1 having $\mathrm{CH}-\pi$ at different sites than $\mathbf{2}$ or the gas phase structure of $[\mathrm{TpBeOH}]_{3}$.

This unusual structural motif in scorpionate ligand complexes, which usually form three bonds to the central metal ion, is well known for $\mathrm{TpBeOH}$ and we could demonstrate why it is energetically more favoured than the dimer, which is usually found within other scorpionate metal hydroxide complexes. ${ }^{[14]}$

\section{Experimental Section}

Caution! Beryllium and its compounds are regarded as highly toxic ${ }^{[1,10,11]}$ and carcinogenic and have allergic potential when inhaled, with risk of causing chronic beryllium disease (CBD). They should therefore be handled with appropriate safety precautions. All experiments described herein were performed in fume hoods, in gloveboxes, or with standard Schlenk techniques under $\mathrm{Ar}$ atmosphere. Toluene was dried over $\mathrm{Na} / \mathrm{K}$ alloy and degassed before use. $\mathrm{TpBeCl}$ was prepared by literature method $^{[13]}$ and purified by re-crystallization. Highly pure water and $D_{2} \mathrm{O}$ were purchased from Sigma Aldrich and used without further purification. NMR spectra were recorded on a Bruker Avance 300 NMR spectrometer at $25{ }^{\circ} \mathrm{C}$ at $300.1 \mathrm{MHz}\left({ }^{1} \mathrm{H}\right), 46.1 \mathrm{MHz}\left({ }^{2} \mathrm{D}\right), 42.4 \mathrm{MHz}\left({ }^{9} \mathrm{Be}\right), 32.2 \mathrm{MHz}$ $\left({ }^{10} \mathrm{~B}\right), 96.3 \mathrm{MHz}\left({ }^{11} \mathrm{~B}\right), 75.5 \mathrm{MHz}\left({ }^{13} \mathrm{C}\right)$ and $21.7 \mathrm{MHz}\left({ }^{14} \mathrm{~N}\right)$, respectively. ${ }^{1} \mathrm{H}$ and ${ }^{13} \mathrm{C}\left\{{ }^{1} \mathrm{H}\right\}$ NMR spectra were referenced to internal toluene- $d_{8}$ $\left(\delta\left({ }^{1} \mathrm{H}\right)=2.08,6.97,7.01,7.09 \mathrm{ppm} ; \delta\left({ }^{13} \mathrm{C}\right)=20.43,125.13,127.96\right.$, $128.87,137.48 \mathrm{ppm})$ and ${ }^{2} \mathrm{D}$ NMR spectra to neat TMS- $d_{12}\left(\delta\left({ }^{2} \mathrm{D}\right)=0\right.$ ppm). ${ }^{9} \mathrm{Be}$ NMR spectra were referenced to external $\mathrm{BeSO}_{4}$ in $\mathrm{D}_{2} \mathrm{O}$ $\left(\delta\left({ }^{9} \mathrm{Be}\right)=0 \mathrm{ppm}\right),{ }^{14} \mathrm{~N}\{1 \mathrm{H}\} \mathrm{NMR}$ spectra to external $\mathrm{CH}_{3} \mathrm{NO}_{2}\left(\delta\left({ }^{14} \mathrm{~N}\right)=0\right)$ and ${ }^{10} \mathrm{~B} /{ }^{11} \mathrm{~B}$ NMR spectra to external $15 \% \mathrm{BF}_{3} \cdot \mathrm{OEt}_{2}$ in $\mathrm{CDCl}_{3}\left(\delta\left({ }^{10} \mathrm{~B}\right)=0\right.$ ppm and $\left.\delta\left({ }^{11} B\right)=0\right)$. IR spectra were recorded with an Alpha-T FT-IR spectrometer with a single reflection ATR sampling module. Elemental analyses were not determined because of the potential toxicity of the complexes.

General procedure for the synthesis of $\operatorname{TpBeX}(X=\mathrm{OH} 1, \mathrm{OD} 2)$. $\mathrm{TpBeCl}(350 \mathrm{mg}, 1.36 \mathrm{mmol}$ ) was dissolved in $24 \mathrm{~mL}$ of toluene and 231 $\mu \mathrm{L}$ DIPEA (176 mg, $1.36 \mathrm{mmol}$ ) were added at ambient temperature. 25 $\mu \mathrm{L} \mathrm{H}_{2} \mathrm{O}(25 \mathrm{mg}, 1.36 \mathrm{mmol})$ respectively $25 \mu \mathrm{L} \mathrm{D} \mathrm{O}_{2}(27 \mathrm{mg}, 1.36 \mathrm{mmol})$ were added to the solution under vigorous stirring. The reaction mixture was stirred for $1 \mathrm{~h}$, resulting in the formation of a white precipitate, which was isolated by filtration. The remaining clear solution was concentrated to $4 \mathrm{~mL}$, yielding a white solid that was re-dissolved by gentle heating. The resulting clear solution was stored at $-30{ }^{\circ} \mathrm{C}$ for $3 \mathrm{~h}$ to give $\mathbf{1}$ and $\mathbf{2}$, respectively, in quantitative crystalline yields. The analytical data of 1 agreed with those reported in the literature. ${ }^{[12]}$

TpBeOH (1): Yield $325 \mathrm{mg}(>99 \%) .{ }^{1} \mathrm{H}-\mathrm{NMR}\left(300 \mathrm{MHz}, \mathrm{C}_{7} \mathrm{D}_{8}, 20^{\circ} \mathrm{C}\right): \delta$ $=4.84\left(\mathrm{~s} \mathrm{broad}, 3 \mathrm{H}, \mathrm{HB}(\mathrm{N}(\mathrm{CHCHCH}) \mathrm{N})_{2}(\mathrm{~N}(\mathrm{CHCHCH}) \mathrm{N}) \mathrm{BeOH}\right), 5.88(\mathrm{t}$ $\left.6 \mathrm{H}, \mathrm{HB}(\mathrm{N}(\mathrm{CHCHCH}) \mathrm{N})_{2}(\mathrm{~N}(\mathrm{CHCHCH}) \mathrm{N}) \mathrm{BeOH}\right), 5.92\left(\mathrm{t},{ }^{3} \mathrm{JHH}_{\mathrm{HH}}=2.1 \mathrm{~Hz}\right.$, $\left.3 \mathrm{H}, \mathrm{HB}(\mathrm{N}(\mathrm{CHCHCH}) \mathrm{N})_{2}(\mathrm{~N}(\mathrm{CHCHCH}) \mathrm{N}) \mathrm{BeOH}\right), 7.36\left(\mathrm{~d},{ }^{3} \mathrm{JHH}_{\mathrm{HH}}=2.0 \mathrm{~Hz}\right.$, $\left.6 \mathrm{H}, \mathrm{HB}(\mathrm{N}(\mathrm{CHCHCH}) \mathrm{N})_{2}(\mathrm{~N}(\mathrm{CHCHCH}) \mathrm{N}) \mathrm{BeOH}\right), 7.64\left(\mathrm{~d},{ }^{3} \mathrm{JHH}_{\mathrm{HH}}=1.7 \mathrm{~Hz}\right.$ $\left.3 \mathrm{H}, \mathrm{HB}(\mathrm{N}(\mathrm{CHCHCH}) \mathrm{N})_{2}(\mathrm{~N}(\mathrm{CHCHCH}) \mathrm{N}) \mathrm{BeOH}\right), 7.72\left(\mathrm{~d},{ }^{3} \mathrm{H}_{\mathrm{HH}}=1.9 \mathrm{~Hz}\right.$, $\left.6 \mathrm{H}, \quad \mathrm{HB}(\mathrm{N}(\mathrm{CHCHCH}) \mathrm{N})_{2}(\mathrm{~N}(\mathrm{CHCHCH}) \mathrm{N}) \mathrm{BeOH}\right), \quad 8.47$ (s, $3 \mathrm{H}$, $\left.\mathrm{HB}(\mathrm{N}(\mathrm{CHCHCH}) \mathrm{N})_{2}(\mathrm{~N}(\mathrm{CHCHCH}) \mathrm{N}) \mathrm{BeOH}\right) .{ }^{9} \mathrm{Be}-\mathrm{NMR}\left(\mathrm{C}_{7} \mathrm{D}_{8}, 42.2 \mathrm{MHz}\right)$ : $\delta=4.40\left(\mathrm{~s}, \mathrm{HB}(\mathrm{N}(\mathrm{CHCHCH}) \mathrm{N})_{2}(\mathrm{~N}(\mathrm{CHCHCH}) \mathrm{N}) \mathrm{BeOH}\right) .{ }^{10} \mathrm{~B}-\mathrm{NMR}(34.2$ $\left.\mathrm{MHz}, \mathrm{C}_{7} \mathrm{D}_{8}, 25{ }^{\circ} \mathrm{C}\right): \delta=-2.48 .{ }^{11} \mathrm{~B}-\mathrm{NMR}\left(96.3 \mathrm{MHz}, \mathrm{C}_{7} \mathrm{D}_{8}, 25^{\circ} \mathrm{C}\right): \delta=$ -2.48. ${ }^{13} \mathrm{C}$ NMR $\left(125 \mathrm{MHz}, \mathrm{C}_{7} \mathrm{D}_{8}, 25{ }^{\circ} \mathrm{C}\right): \delta=104.1,105.4,134.7,136.5$, 137.5, 138.2, 140.4. IR (ATR, $25^{\circ} \mathrm{C}, 32$ scans): $v=3233(\mathrm{w}) 2945(\mathrm{w})$, $2826(w), 2453(w), 1664(w), 1579(w), 1507(w), 1456(w), 1409(w)$, $1384(w), 1309(w), 1291(w), 1260(w), 1226(w), 1214(w), 1179(w)$, $1124(w), 1098(w), 1042(w), 995(m), 936(m), 914(w), 883(m), 798$ (m), $773(\mathrm{~m}), 752(\mathrm{w}), 732(\mathrm{~m}), 716(\mathrm{~m}), 664(\mathrm{~m}), 607(\mathrm{w}), 500(\mathrm{w}), 471$ (s), $426(\mathrm{~m}), 401(\mathrm{~m}) \mathrm{cm}^{-1}$.

TpBeOD (2): Yield $326 \mathrm{mg}(>99 \%) .{ }^{1} \mathrm{H}-\mathrm{NMR}\left(300 \mathrm{MHz}, \mathrm{C}_{7} \mathrm{D}_{8}, 20^{\circ} \mathrm{C}\right): \delta$ $=4.84\left(\mathrm{~s}\right.$ broad, $\left.3 \mathrm{H}, \mathrm{HB}(\mathrm{N}(\mathrm{CHCHCH}) \mathrm{N})_{2}(\mathrm{~N}(\mathrm{CHCHCH}) \mathrm{N}) \mathrm{BeOD}\right), 5.89$ $\left(\mathrm{t}, 6 \mathrm{H}, \mathrm{HB}(\mathrm{N}(\mathrm{CHCHCH}) \mathrm{N})_{2}(\mathrm{~N}(\mathrm{CHCHCH}) \mathrm{N}) \mathrm{BeOD}\right), 5.92\left(\mathrm{t},{ }^{3} \mathrm{JHH}_{\mathrm{HH}}=2.1 \mathrm{~Hz}\right.$, $\left.3 \mathrm{H}, \mathrm{HB}(\mathrm{N}(\mathrm{CHCHCH}) \mathrm{N})_{2}(\mathrm{~N}(\mathrm{CHCHCH}) \mathrm{N}) \mathrm{BeOD}\right), 7.36\left(\mathrm{~d},{ }^{3} \mathrm{JHH}_{\mathrm{HH}}=2.0 \mathrm{~Hz}\right.$, $\left.6 \mathrm{H}, \mathrm{HB}(\mathrm{N}(\mathrm{CHCHCH}) \mathrm{N})_{2}(\mathrm{~N}(\mathrm{CHCHCH}) \mathrm{N}) \mathrm{BeOD}\right), 7.64\left(\mathrm{~d},{ }^{3} \mathrm{JHH}_{\mathrm{HH}}=1.7 \mathrm{~Hz}\right.$, $\left.3 \mathrm{H}, \mathrm{HB}(\mathrm{N}(\mathrm{CHCHCH}) \mathrm{N})_{2}(\mathrm{~N}(\mathrm{CHCHCH}) \mathrm{N}) \mathrm{BeOD}\right), 7.72\left(\mathrm{~d},{ }^{3} \mathrm{JHH}_{\mathrm{HH}}=1.9 \mathrm{~Hz}\right.$ $\left.6 \mathrm{H}, \quad \mathrm{HB}(\mathrm{N}(\mathrm{CHCHCH}) \mathrm{N})_{2}(\mathrm{~N}(\mathrm{CHCHCH}) \mathrm{N}) \mathrm{BeOD}\right), \quad 8.47 \quad(\mathrm{~s}, \quad 0.3 \mathrm{H}$, $\left.\mathrm{HB}(\mathrm{N}(\mathrm{CHCHCH}) \mathrm{N})_{2}(\mathrm{~N}(\mathrm{CHCHCH}) \mathrm{N}) \mathrm{BeO} D(H)\right) .{ }^{9} \mathrm{Be}-\mathrm{NMR} \quad\left(\mathrm{C}_{7} \mathrm{D}_{8}, 42.2\right.$ $\mathrm{MHz}): \delta=4.40 .{ }^{10} \mathrm{~B}-\mathrm{NMR}\left(34.2 \mathrm{MHz}, \mathrm{C}_{7} \mathrm{D}_{8}, 25{ }^{\circ} \mathrm{C}\right): \delta=-2.53 .{ }^{11} \mathrm{~B}-\mathrm{NMR}$ (96.3 MHz, $\left.\mathrm{C}_{7} \mathrm{D}_{8}, 25{ }^{\circ} \mathrm{C}\right): \delta=-2.53 .{ }^{13} \mathrm{C}-\mathrm{NMR}\left(125 \mathrm{MHz}, \mathrm{C}_{7} \mathrm{D}_{8}, 25^{\circ} \mathrm{C}\right): \delta$ $=104.1,105.4,134.7,136.5,137.5,138.2,140.4) .{ }^{1} \mathrm{H}$ NMR $(300 \mathrm{MHz}$, $\left.\mathrm{C}_{7} \mathrm{H}_{8}, \quad 20 \quad{ }^{\circ} \mathrm{C}\right): \quad \delta=4.84$ (s broad, $3 \mathrm{H}$, $\left.\mathrm{HB}(\mathrm{N}(\mathrm{CHCHCH}) \mathrm{N})_{2}(\mathrm{~N}(\mathrm{CHCHCH}) \mathrm{N}) \mathrm{BeOD}\right), \quad 5.89$ ${ }^{3} J_{\mathrm{HH}}=1.9 \mathrm{~Hz},{ }^{3} \mathrm{JHH}_{\mathrm{HH}}=1.7 \mathrm{~Hz}, 6 \mathrm{H}, \mathrm{HB}(\mathrm{N}(\mathrm{CHCHCH}) \mathrm{N})_{2}(\mathrm{~N}(\mathrm{CHCHCH}) \mathrm{N}) \mathrm{Be}$ $\mathrm{OD}), \quad 5.92 \quad\left(\mathrm{t}, \quad{ }^{3} \mathrm{JHH}_{\mathrm{HH}}=2.1 \mathrm{~Hz}, 3 \mathrm{H}\right.$, $\left.\mathrm{HB}(\mathrm{N}(\mathrm{CHCHCH}) \mathrm{N})_{2}(\mathrm{~N}(\mathrm{CHCHCH}) \mathrm{N}) \mathrm{BeOD}\right), 7.36\left(\mathrm{~d},{ }^{3} \mathrm{JHH}_{\mathrm{HH}}=2.0 \mathrm{~Hz}, 6 \mathrm{H}\right.$, $\left.\mathrm{HB}(\mathrm{N}(\mathrm{CHCHCH}) \mathrm{N})_{2}(\mathrm{~N}(\mathrm{CHCHCH}) \mathrm{N}) \mathrm{BeOD}\right), 7.64\left(\mathrm{~d},{ }^{3} \mathrm{JHH}_{\mathrm{HH}}=1.7 \mathrm{~Hz}, 3 \mathrm{H}\right.$ $\left.\mathrm{HB}(\mathrm{N}(\mathrm{CHCHCH}) \mathrm{N})_{2}(\mathrm{~N}(\mathrm{CHCHCH}) \mathrm{N}) \mathrm{BeOD}\right), 7.72\left(\mathrm{~d},{ }^{3} \mathrm{JHH}_{\mathrm{HH}}=1.9 \mathrm{~Hz} 6 \mathrm{H}\right.$, $\left.\mathrm{HB}(\mathrm{N}(\mathrm{CHCHCH}) \mathrm{N})_{2}(\mathrm{~N}(\mathrm{CHCHCH}) \mathrm{N}) \mathrm{BeOD}\right), \quad 8.47 \quad(\mathrm{~s}, \quad 0.3 \mathrm{H}$, $\left.\mathrm{HB}(\mathrm{N}(\mathrm{CHCHCH}) \mathrm{N})_{2}(\mathrm{~N}(\mathrm{CHCHCH}) \mathrm{N}) \mathrm{BeO} D(H)\right) .{ }^{9} \mathrm{Be}-\mathrm{NMR} \quad\left(\mathrm{C}_{7} \mathrm{D}_{8}, 42.2\right.$ $\mathrm{MHz}): \delta=4.38 .{ }^{11} \mathrm{~B}-\mathrm{NMR}\left(96.29 \mathrm{MHz}, \mathrm{C}_{7} \mathrm{D}_{8}, 25{ }^{\circ} \mathrm{C}\right): \delta=-6.95 .{ }^{13} \mathrm{C}-\mathrm{NMR}$ $\left(125 \mathrm{MHz}, \mathrm{C}_{7} \mathrm{D}_{8}, 25^{\circ} \mathrm{C}\right): \delta=95.87,97.21,126.49,128.30,129.55,129.95$, 132.16). IR (ATR, $25^{\circ} \mathrm{C}, 32$ scans): v = 3134 (w) 2963 (w), 2459 (w), $2370(w), 1507(w), 1407(w), 1387(m), 1310(m), 1295(m), 1262(w)$, $1191(\mathrm{~m}), 1126(\mathrm{~m}), 1099(\mathrm{~m}), 1068(\mathrm{~m}), 997(\mathrm{~m}), 960(\mathrm{~m}), 924(\mathrm{~m}), 908$ $(\mathrm{m}), 797(\mathrm{~s}), 770(\mathrm{~m}), 721(\mathrm{~m}), 682(\mathrm{~m}), 668(\mathrm{~m}), 621(\mathrm{~m}), 609(\mathrm{~m}), 467$ (w) $\mathrm{cm}^{-1}$.

[thf $\mathrm{BeOH}_{3} \mathrm{Br}_{3} \cdot \mathrm{CHCl}_{3}$ (3): A solution of $250 \mathrm{mg}(1.48 \mathrm{mmol}) \mathrm{BeBr}_{2}$ in 2 $\mathrm{mL}$ thf was mixed with $25 \mathrm{~mL}$ of wet $\mathrm{CHCl}_{3}$. The resulting solution was stored in the fume-hood in a crystallization beaker to evaporate the solvent. After 2 days pale brown crystals could be isolated from the saturated solution. Yield $207 \mathrm{mg} 56 \%(0.83 \mathrm{mmol})$. ${ }^{1} \mathrm{H}-\mathrm{NMR}(300 \mathrm{MHz}$, $\left.\mathrm{CD}_{2} \mathrm{Cl}_{2}, 20^{\circ} \mathrm{C}\right): \delta=1.88\left(\mathrm{~m}, 4 \mathrm{H}, \mathrm{O}\left(\mathrm{CH}_{2} \mathrm{CH}_{2}\right)\right), 2.13\left(\mathrm{~m}, 4 \mathrm{H}, \mathrm{O}\left(\mathrm{CH}_{2} \mathrm{CH}_{2}\right)\right)$, $3.48\left(\mathrm{~m}, 4 \mathrm{H}, \mathrm{O}\left(\mathrm{CH}_{2} \mathrm{CH}_{2}\right)\right), 3.85\left(\mathrm{~m}, 4 \mathrm{H}, \mathrm{O}\left(\mathrm{CH}_{2} \mathrm{CH}_{2}\right)\right)$. ${ }^{9} \mathrm{Be}-\mathrm{NMR}\left(\mathrm{CD}_{2} \mathrm{Cl}_{2}\right.$, $42.2 \mathrm{MHz}): \delta=8.38,9.69$.

Single crystal X-ray analyses. Crystallographic data of $\mathbf{1}-\mathbf{3}$, which were collected on a Bruker AXS SMART diffractometer (MoK $\alpha$ radiation, $\lambda=0.71073 \AA$ ) at $100(1) \mathrm{K}(\mathbf{1}, \mathbf{2})$ and $153(1) \mathrm{K}(\mathbf{3})$ are summarized in Table S1 (SI). The solid-state structures of $\mathbf{1}$ and $\mathbf{2}$ are shown in Figures 1 and 2, that of $\mathbf{3}$ in the SI. The structures were solved by Direct Methods (SHELXS-97) and refined anisotropically by full-matrix least-squares on $\mathrm{F}^{2} \quad$ (SHELXL-97/SHELXL-2013). ${ }^{[22]}$ Absorption corrections were performed semi-empirically from equivalent reflections on basis of multiscans (Bruker AXS APEX2). Hydrogen atoms were refined using a riding model or rigid methyl groups. $\mathrm{OH}$ and $\mathrm{BH}$ hydrogen atoms were refined freely with its $\mathrm{OH}$ and $\mathrm{BH}$ bond length, respectively, restrained to be equal (SADI). The bond lengths of the corresponding atoms of the components of the disorder were restraint to be equal (SADI) In 1 the bond lengths of the corresponding atoms of the components of the disorder were restraint to be equal (SADI) The toluene molecule is disordered over a centre of inversion. To the ADP of the disordered atoms RIGU restraints were applied. In $\mathbf{3}$ the $\mathrm{OH}$ hydrogen atoms were taken from the difference Fourier synthesis and fixed..The crystallographic data of $\mathbf{1}$ - $\mathbf{3}$ (excluding structure factors) have been deposited with the Cambridge Crystallographic Data Centre as supplementary publication nos. CCDC-1441472 (1), 1441473 (2) and 1441471 (3). Copies of the data can be obtained free of charge on application to CCDC, 12 Union Road, Cambridge, CB21EZ (fax: (+44) 1223/336033; e-mail: deposit@ccdc.cam-ak.uk). 
Supporting Information. A CIF file giving X-ray crystallographic data of 1 - 3. In addition, (temperature-dependant) ${ }^{1} \mathrm{H}$ and ${ }^{13} \mathrm{C}$ NMR data of $\mathbf{1}-\mathbf{3}$ as well as computational details (gas phase structures, NBO and SEN analyses, CSM-corrections) are given. This material is available free of charge via the Internet at http://pubs.acs.org.

\section{Acknowledgements}

S. Schulz and G. Jansen gratefully acknowledge financial support by the University of Duisburg-Essen.

Keywords: Beryllium $\bullet$ Scorpionate $\cdot$ Computational chemistry

\section{References}

[1] a) T. Handa, S. Nagai, M. Kitaichi, K. Chin, Y. Ito, T. Oga, K. Takahashi, K. Watanabe, M. Mishima, T. Izumi, Sarcoidosis Vasculitis and Diffuse Lung Diseases 2009, 26, 24-31; b) C. Strupp, Ann. Occup. Hyg. 2011 55, 43-56; c) C. Strupp, Ann. Occup. Hyg. 2011, 55, 30-42; d) K. J. Cummings, A. B. Stefaniak, M. Abbas Virji, K. Kreiss, Environmental Health Perspectives 2009, 117, 1250-1256; e) J. R. Bill, D. G. Mack, M. T. Falta, L. A. Maier, A. K. Sullivan, F. G. Joslin, A. K. Martin, B. M. Freed, B. L. Kotzin, A. P. Fontenot, J. Immunology 2005, 175 70297037.

[2] S. C. Chmely, T. P. Hanusa, W. W. Brennessel, Angew. Chem. Int. Ed 2010, 49, 5870-5874; Angew. Chem. 2010,122, 6006-6010.

[3] R. J. Gilliard, M. Y. Abraham, Y. Wang, P. Wei, Y. Xie, B. Quillian, H. F. Schaefer, P. v. R. Schleyer, G. H. Robinson, J. Am. Chem. Soc. 2012 134, 9953-9955

[4] J. Gottfriedsen, S. Blaurock, Organometallics 2006, 25, 3784-3786.

[5] M. S. Hill, M. Arrowsmith, G. Kociok-Köhn, D. J. MacDougall, M. F. Mahon, Angew. Chem. Int. Ed. 2012, 51, 2098-2100; Angew. Chem. 2012, 124, 2140-2142.

[6] a) H. Braunschweig, K. Grussand, K. Radacki, Angew. Chem. Int. Ed. 2009, 48, 4239-4241; Angew. Chem. 2009, 123, 4303-4305; b) F Kraus, M. B. Fichtl, S. A. Baer, Z. Naturforsch. 2009, 64b, 257-262; c) F Kraus, S. A. Baer, M. Hoelzel, A. J. Karttunen, Eur. J. Inorg. Chem 2013, 4184-4190; d) R. Puchta, B. Neumüller, K. Dehnicke, Z. Anorg. Allg. Chem. 2009, 635, 1196-1199.

[7] For a very recent review article see: K. J. Iversen, S. A. Couchman, D. J.D. Wilson, J. L. Dutton, Coord. Chem. Rev. 2015, 297-298, 40-48.
[8] S. A. Couchman, N. Holzmann, G. Frenking, D. J. D. WilsonandJ. L. Dutton, Dalton Trans. 2013, 42, 11375-11384

[9] F. Kraus, S. Baer, M. R. Buchner, A. J. Karttunen, Chem. Eur. J. 2012 18, 2131-2142.

[10] H. Schmidbaur, Coord. Chem. Rev. 2001, 215, 223-242.

[11] K. Dehnicke, B. Neumüller, Z. Anorg. Allg. Chem. 2008, 634, 27032728.

[12] D. Naglav, D. Bläser, C. Wölper, S. Schulz, Inorg. Chem. 2014, 53 1241-1249.

[13] a) Y.Sohrin, H.Kokusen, S.Kihara, M.Matsui, Y.Kushi, M.Shiro, Chem Lett. 1992, 1461; b) Y. Sohrin, H. Kokusen, S. Kihara, M. Matsui, Y Kushi, M. Shiro, J. Am. Chem. Soc. 1993, 115, 4128-4136.

[14] Cambridge Structural Database, Version 5.36, see also: F. H. Allen, Acta Cryst., 2002, B58, 380-388.

[15] RIDFTD3 a) O. Treutler, R. Ahlrichs; J. Chem. Phys. 1995, 102, 346 354; b) K. Eichkorn, O. Treutler, H. Öhm, M. Häser, R. Ahlrichs, Chem Phys. Lett. 1995, 242, 652-660; c) K. Eichkorn, F. Weigend, O. Treutler R. Ahlrichs, Theor. Chem. Acc. 1997, 97, 119-124; d) M. v. Arnim, R. Ahlrichs, J. Comp. Chem. 1998, 19, 1746-1757; e) S. Grimme, J Antony, S. Ehrlich, H. Krieg, J. Chem. Phys. 2010, 132, 154104.

[16] J. P. Perdew, K. Burke, M. Ernzerhof, Phys. Rev. Lett. 1996, 77, 3865 3868.

[17] F. Weigend, R. Ahlrichs, Phys. Chem. Chem. Phys. 2005, 7, 3297-3305.

[18] R. Ahlrichs, M. Bär, M. Häser, H. Horn, C. Kölmel, Chem. Phys. Lett. 1989, 162, 165-169

[19] a) F. Weigend, M. Häser, Theor. Chem. Acc. 1997, 97, 331-340; b) F. Weigend, M. Häser, H. Patzelt, R. Ahlrichs; Chem. Phys. Lett. 1998 294, 143-152; c) A. Hellweg, S. A. Grün, C. Hättig, Phys. Chem. Chem. Phys. 2008, 10, 4119-4127.

[20] a) A. Klamt, G. Schüürmann, Perkin. Trans. 2, 1993, 799-805; b) A Klamt, V. Jonas, J. Chem. Phys. 1996, 105, 9972-9981.

[21] a) F. Cecconi, C. A. Ghilardi, S. Midollini, A. Orlandini, Inorg. Chem. 1998, 37, 146.; b) R. Faure, F. Bertin, H. Loiseleur, G. Thomas-David Acta Crystallogr., Sect. B 1974, 30, 462; c) Y. Sohrin, M. Matsui, Y. Hata, H. Hasegawa, H. Kokusen, Inorg. Chem. 1994, 33, 4376; d) P. Barbaro, F. Cecconi, C. A. Ghilardi, S. Midollini, A. Orlandini, L. Alderighi, D. Peters, A. Vacca, E. Chinea, A. Mederos, Inorg. Chim Acta 1997, 262, 187.

[22] G. M. Sheldrick, Acta Crystallogr. Sect. A 1990, 46, 467-473., G. M. Sheldrick, SHELXL-97, Program for the Refinement of Crysta Structures University of Göttingen, Göttingen (Germany) 1997 (see also: G. M. Sheldrick, Acta Crystallogr. Sect. A 2008, 64, 112-122). 
Entry for the Table of Contents (Please choose one layout)

Layout 1:

\section{SHORT COMMUNICATION}

Two trimeric beryllium hydroxide scorpionate complexes $\left[\mathrm{Be}_{3}(\mu\right.$ $\left.\mathrm{OX})_{3}(\mathrm{Tp})_{3}\right](\mathrm{X}=\mathrm{H} \mathrm{1}, \mathrm{D} 2)$ and $\left[\mathrm{BeBr}_{3}(\mu-\mathrm{OH})_{3}(\mathrm{Br})_{3}(\text { thf })_{6}\right]$ were structurally characterized. The six membered $\mathrm{Be}_{3} \mathrm{O}_{3}$ ring of 1 is stable in solution and gas phase as was shown by temperature dependent ${ }^{1} \mathrm{H}$ - and ${ }^{9} \mathrm{Be}$ NMR spectroscopy and theoretical calculations.

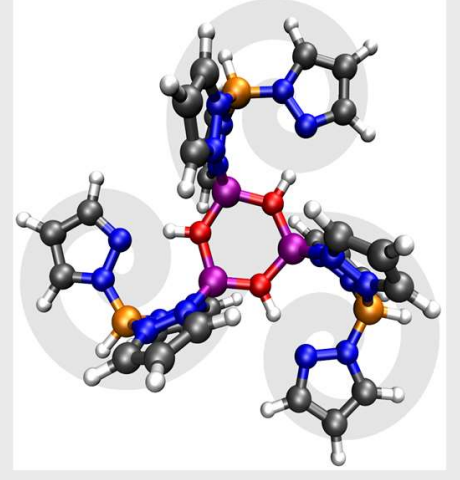

\section{Be Scorpionates}

Dominik Naglav, Briac Tobey, Christoph Wölper, Dieter Bläser, Georg Jansen and Stephan Schulz*

Page No. - Page No.

Title 
DuEPublico

Duisburg-Essen Publications online

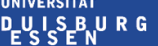

offen im Denken

\section{$\mathbf{U b} \mid \begin{gathered}\text { universitäts } \\ \text { bibliothek }\end{gathered}$}

This text is made available via DuEPublico, the institutional repository of the University of Duisburg-Essen. This version may eventually differ from another version distributed by a commercial publisher.

DOI: $\quad 10.1002 /$ ejic.201501433

URN: urn:nbn:de:hbz:464-20201203-162805-4

This is the peer reviewed version of the following article: Eur. J. Inorg. Chem. 2016,15-16, 2424-2431, which has been published in final form at:

https://doi.org/10.1002/ejic.201501433

All rights reserved. 